\title{
Commercial banks' competitive Countermeasures under the background of Internet Finance WANG Xin
}

\author{
Sichuan Post and Telecommunication College, Sichuan Chengdu 610000,China \\ Wamgxinsc@163.com
}

Keywords: Internet banking; commercial bank; competition; strategy

\begin{abstract}
In recent years, with economic progress and the development of the Internet, "Internet plus" mode gradually integrated into the various sectors of society, caused widespread concern. The integration of Internet and finance marks the official entry into the era of Internet banking. With the advancement of the process of financial liberalization, Internet banking in the transaction costs, transaction convenience level highlights its own unique advantages, and constantly seize customer resources, the development of commercial banks to form a huge impact. In order to meet the needs of the financial market and meet the market demand, commercial banks must deepen the reform and innovate their business forms. This paper describes the challenges faced by commercial banks in the era of Internet banking, and puts forward corresponding countermeasures.
\end{abstract}

\section{Introduction}

He integration of the Internet and the financial industry marks the advent of the Internet era of finance. Under the background of the new era, financial innovation products continue to flock to the traditional commercial banks and Internet banking business boundaries tend to weaken, the commercial banks have a huge impact on earnings, management and management model.

\section{Challenges faced by commercial banks in the context of Internet Banking}

In recent years, the rapid development of Internet banking, its convenience has a tremendous impact on the traditional commercial bank advantage, banks gradually reduce in the basic level of financial business competitiveness in the Internet industry chain in the position to continue to decline, commercial banks gradually become the only mention the end mechanism for back office services. Specific performance as follows:

The bank's traditional credit business and intermediary business are facing competition. Ali small loan since its inception in 2012, its business coverage has been a number of regions and cities across the country. Domestic Internet giants have begun to try financial services, the introduction of a variety of micro credit services. China peace with the Tencent, Taobao cooperation, jointly established Zhongan online property insurance company. According to incomplete statistics, the current domestic Internet lending platform in 2013 the total turnover exceeded 20 billion yuan. The Internet and the financial industry to create a whole new in-depth integration of financial model, e-commerce platform has gradually involved in the financing business, with the rapid increase of trade scale, a significant impact on the profitability of commercial banks.

The main status of payment in commercial banks is challenged. Domestic Internet giant has always maintained in the financial sector concerns, new payment instruments and payment platform, relying on the development of e-commerce platform, has been a threat to the core status in the payment activities of the banks occupy. In fact, the third party payment companies gradually enter the field of international settlement, domestic, fast money has been involved in the field of settlement, the fund field, to carry out insurance platform consignment business. Alibaba to provide services to foreign buyers to pay domestic buyers. The third party payment market, "Alipay" occupy a strong dominant position. Relevant statistics show that Alibaba, Tmall, Taobao in 2012 the total amount of transactions exceeded 10000 yuan, almost the same as the total size of the domestic banks to pay. 
The traditional customer service model of commercial banks is facing the test. Internet banking has a huge impact on the traditional service model of commercial banks, breaking the original situation with a single customer as the goal, the overall service capabilities of commercial banks to challenge. In addition, in the payment, credit and other basic business scope, the dominant position occupied by commercial banks are affected. In recent years, the application of Internet in all areas of society and the deepening of integration of information technology and financial business network platform, together build a new business model, including massive transaction data, network ecological chain etc.. The development of a new type of network payment instruments has a great impact on the core business of commercial banks.

\section{Commercial banks in the context of Internet banking competition strategy}

"Internet plus" mode and the financial industry rapidly merging completely change the domestic financial market situation, have a huge impact on commercial banks. In this regard, commercial banks should correctly understand and distinguish the positive and negative effects. To their own advantages, eliminate the negative impact, follow the market trend, efforts to develop new business areas to accelerate their pace of change, build scientific and perfect coping strategies, to better adapt to the era of Internet Banking under the background of financial market, to provide customers with quality service, enhance their core competitiveness. This paper puts forward the following suggestions for commercial banks:

Based on the reality of the concept of change management. Faced with the financial impact of the Internet and the rapid changes in the financial market conditions, commercial banks should take positive measures to accurately understand the impact of Internet banking on their own. Compared with internet banking, commercial banks in the prediction of customer, risk, risk control and other aspects have unique advantages, so the development process can not simply imitate the mode of operation of the Internet financial enterprises, and should draw lessons from the advanced Internet financial management concept, learning the successful experience, combined with the actual situation of the creation of a more fit with its own development concept. First of all, the commercial banks should change their ideas, break through the traditional mode of thinking, value management, core business, customer vested interest groups and other factors, improve the degree of adaptation to the market environment, to ensure sustainable development. Secondly, the commercial banks in the pursuit of their own development should boldly absorb scientific management mode of Internet banking and advanced management concept, combined with customer centered principle to construct their own situation of the business philosophy, fully realize the scale value effect. The information age, the development of the Internet is accelerating, commercial banks to update the concept of the first to start from the top. Management should pay attention to the development of Internet financial times, recognize the important role played by science and technology in the development process of innovation efforts, seize the opportunity, meet with their own development problems in the process of formulating corresponding reform measures, to strengthen the combination of the traditional core business and the Internet, launched a new financial business is a commercial bank.

To broaden the scope of business to test the waters of new areas. The rapid development of Internet banking has more clearly show the deficiencies of the commercial bank exists, so in the pursuit of their own development process, the commercial bank must do the traditional business as the premise, continue to expand the scope of business, business content is more abundant, combined with advanced scientific means to open online banking, mobile phone banking, to provide more convenient services for customers. Seek their own business and the integration of the Internet, strengthen communication and cooperation with the Internet financial enterprises, and strive to carry out integrated services to achieve win-win situation with the Internet financial companies. Play its own advantages in the customer base, risk prediction, risk management and control and other traditional advantages, with high-end smart mobile devices and network terminal equipment will be related to information and products to customers push. Through the use of WeChat, micro-blog and other new media to eliminate the distance between themselves and customers, expanding the scope of 
traditional financial services, innovation. According to the characteristics of consumer behavior, in order to obtain customer information based on customer demand, deepen understanding, and strive to meet the individual needs, improve the business experience, increase the commercial bank customer marketing strategy to fundamentally improve the success rate of marketing efforts to obtain customer recognition and trust, strengthen customer loyalty. In addition, commercial banks should own online and offline resources to effectively integrate the business, through the electronic bank construction, network construction to build their own development environment, and ultimately create perfect electronic bank value system. In the face of huge impact brought about by the Internet banking, commercial banks want to maintain the ability to survive, to show the core competitiveness, integration must seek capital liquidation mode and the development of electronic commerce mode, and increase the proportion of Internet factors, the introduction of the new "Internet plus" mode of thinking in its operation and management level, make full use of the advantage of customer groups, set up business bigger. The collection, storage and analysis of customer data in e-commerce platform. Relying on the mall platform for platform users to provide quality financial services, such as payment, lending, financing, etc.. Through the line of credit evaluation integration based assessment model, to obtain the electronic commerce platform based on customer information, with the help of the traditional channels to evaluate the financing needs of customers and the overall risk, promote the traditional business platform to comprehensive development platform, achieve the function of sharing network, services, products.

Strengthen internal control and strengthen risk management. As a large enterprise, commercial bank customers have a high degree of trust. In order to improve the level of internal management and control, improve operational fluency, commercial banks should be based on Internet technology to carry out internal information construction, and promote the management of information technology. In recent years, the rapid development of Internet banking is a new challenge to the commercial bank management mode and service concept, basic business continue to impact the commercial bank financial intermediaries, payment etc., affect its traditional core business, leading to bank profit space narrowing, reduce economic benefits, risk management process in the face of more and more. Under the background of the new era, commercial banks should adhere to the spirit of innovation, make appropriate adjustments to their business processes and structures, and strive to adapt to market trends and changes. Learn the advanced experience and successful mode of Internet financial enterprises, the introduction of "Internet plus" new mode of thinking, in-depth integration of all resources online and offline, and on the basis of strengthening the finance companies and Internet communication, seek cooperation, through joint efforts, the development of a more favorable environment for the creation of each other. In addition, to play their own advantages in risk management control, risk identification level, increase financial risk management and control efforts to provide customers with safe services to protect their own interests. The introduction of big data thinking, innovative management philosophy, in order to cope with the increasing operational risk probability.

To achieve the traditional business upgrade to provide customers with a variety of services. Compared with the Internet financial institutions, commercial banks have their own advantages in the customer base. With the development of Finance and Internet

Deep integration of the model, the convenience of Internet banking has resulted in the loss of commercial bank customers. In order to improve the customer loyalty of their own, keep the traditional advantages, commercial banks must implement the re positioning and classification of target customers, combined with large data analysis techniques to implement customer types, deepen the understanding of customer needs, to provide targeted services, enhance customer service experience, and thus enhance their attractiveness to customers. In addition, commercial banks should learn from internet financial success experience, to maintain a high degree of attention to the emerging field of Internet, to broaden the scope of business, increase business types, strengthening the application of electronic technology and digital technology in business development, the development of electronic banking. Commercial banks can make use of the thinking mode of implementation of big data mining the potential customers, customers are invited to experience 
online banking, mobile phone banking convenience in handling business for customers, using the Internet to carry out a variety of financial business. In the process of marketing, we should pay close attention to the customer's psychology, and summarize the consumption patterns on the basis of the customer's consumption habits, set up online payment and other convenient services to enhance the customer experience, try to meet the individual needs. In the development of commercial banks, only always adhere to customer-centric business philosophy, a better understanding of customer needs and to provide good service, truly meet customer needs, in order to fundamentally enhance their ability to survive, to deal with the fierce market competition, to maintain rapid and healthy development.

Strengthening the construction of talents and cultivating the talents of compound Finance. New mode of "Internet plus", the domestic financial industry is developing rapidly, especially the increase of financial professional knowledge and professional skills comprehensive talent gap, talent supply and demand and structural contradictions are more prominent. For their own development, strengthen further integration with the "Internet plus" mode, the commercial bank must recognize the importance of cultivating talents to work, to give enough attention to professional talents, increase the intensity of talent team construction combined with recruitment, training and other means to attract more talents with cross discipline by excellent financial professional knowledge and related skills. To help their own development. Traditional commercial banks in the implementation of talent recruitment, often based on finance and economics majors, with a bachelor's degree or above. The recruitment criteria too much emphasis on talent theory knowledge, ignore the ability of technical factors and actual operation level, resulting in recruiting staff lack of follow-up development in occupation literacy, skills, difficult transition to complex financial talents, unable to meet the development needs of commercial banks fundamentally. In the future of the first financial personnel recruitment, on the one hand, emphasis should be put on the counter business operation ability and proficiency, on the other hand, but also in marketing, computer, language and communication ability, settlement, financial management, statistics, and other aspects of the service ability put forward higher requirements to ensure follow-up personnel with sufficient space for development. Better able to show their talents, to provide a powerful boost for the development of commercial banks.

\section{Summary}

In recent years, the rapid development of Internet banking, the proportion of the social financial system gradually increased, resulting in a huge impact on commercial banks. In this context, commercial banks want to stand firm in the fierce market competition, we must uphold the spirit of innovation to carry out the transformation and upgrading work, the development of strict and perfect development strategies to deal with the financial challenges of the internet. Continue to expand the scope of business, to meet the needs of the community and the financial market, to enhance their core competitiveness.

\section{Reference}

[1] Peng Diyun, Li Yang. Study on the symbiotic relationship between Internet banking and commercial banks and the Countermeasures for its interactive development [J]. economic issues, 2015, (): 133-139.

[2] Lu Minfeng, Yu Pengfei. The research on the "big data" strategy of the commercial bank under the background of Internet Finance: Based on the application of Internet banking in the transformation and upgrading of commercial banks [J]. economic and management, 2015,29 (3): 31-38.

[3] Puro L, Teich J E, Wallenius H, et al. Decision for lending[J]. Decision Support Systems, 2010, 49 (1): 52-60. people-to-people (Aid) 
[4] Shenyong Hao, Chen Hui. The Internet Banking for the short-term impact of traditional commercial banks with far-reaching impact [J]. Journal of Shanghai Administration College, 2015,16 (2): 96-104.

[5] Niu Huayong, min Deyin. Internet financial impact on Mechanism of commercial banks -- Based on new empirical industrial organization theory [J]. Journal of Hebei University of Economics and Business, 2015, (3): 66-71. 